\title{
Shrub encroachment alters topsoil C:N:P stoichiometric ratios in a high- altitude forest cutover
}

\author{
Defeng Feng (1-2), \\ Weikai Bao ${ }^{(1)}$
}

\begin{abstract}
The effect of shrub encroachment on soil carbon $(C)$ : nitrogen $(\mathrm{N})$ : phosphorus (P) stoichiometric ratios are largely still unknown. We investigated this effect and the effect of shrub size in a high altitude forest cutover among four common shrub species: Cerasus trichostoma, Ribes glaciale, Rosa omeiensis and Salix sphaeronymphe. The difference in topsoil $\mathrm{C}: \mathrm{N}$ ratio between meadows and shrub islands was greatly influenced by shrub species and plant sizes. Topsoil $\mathrm{N}: \mathrm{P}$ and $\mathrm{C}: \mathrm{P}$ ratios were always higher in shrub islands than in meadows, irrespective of shrub species and plant size. The expansion of shrubs merely increased the topsoil $\mathrm{C}: \mathrm{N}$ ratio beneath Cerasus and Rosa, and increased the topsoil N:P and C:P ratios beneath the four shrub species. The increase in stoichiometric ratio followed an identical pattern among the four shrub species as shrub size increased. There were always higher topsoil C:P and N:P ratios beneath Ribes than under the other shrub species with the same plant size. This study clearly suggests that the effect of shrub islands on soil $\mathrm{C}: \mathrm{N}: \mathrm{P}$ stoichiometric ratios was dependent on shrub species and size. Our results are conducive to clarifying the currently confusion in secondary successional trends of soil C:N:P stoichiometry.
\end{abstract}

\section{Keywords: Plant Species, Shrub Islands, Shrub Size, Soil Stoichiometry}

and anthropic disturbances (Sistla \& Schimel 2012).

Generally, shrub encroachment into grasslands is a key stage of secondary succession under some conditions (e.g., highaltitude cutovers), and involves a transition of vegetation, plant species and microclimate. At global and regional scales, the transformation from grassland to shrubland significantly influences the soil C:N:P stoichiometry (Schipper \& Sparling 2011, Xu et al. 2013). However, a large number of studies have shown contradictory results in soil C:N ratio between grasslands and shrub islands at local scales. Increasing (Schipper \& Sparling 2011, La Mantia et al. 2013), decreasing (Springsteen et al. 2010, Blaser et al. 2014) and even relatively stable (Hughes et al. 2006, Wheeler et al. 2007, McClaran et al. 2008, McKinley \& Blair
(1) CAS Key Laboratory of Mountain Ecological Restoration and Bioresource Utilization \& Ecological Restoration and Biodiversity Conservation Key Laboratory of Sichuan Province, Chengdu Institute of Biology, Chinese Academy of Sciences, Chengdu, 610041 Sichuan (China); (2) Research Institute of Resource Insects, Chinese Academy of Forestry, Kunming, 650224 Yunnan (China)

@ Weikai Bao (baowk@cib.ac.cn)

Received: Mar 30, 2018 - Accepted: Jul 03, 2018

Citation: Feng D, Bao W (2018). Shrub encroachment alters topsoil C:N:P stoichiometric ratios in a high-altitude forest cutover. iForest 11: 594-599. - doi: 10.3832/ifor2803-011 [online 2018-09-25]

Communicated by: Francesco Ripullone
2008) trends of soil C:N ratios have all been reported between grasslands and shrubs. Additionally, La Mantia et al. (2013) observed that the direction of change in a soil $\mathrm{C}: \mathrm{N}$ ratio significantly differed among three contrasting bioclimatic regions along a successional trajectory. Therefore, the variation of soil C:N:P stoichiometric ratios between grassland soils and soils under shrubs should be studied for plant species with wide ranges. Furthermore, it has been demonstrated that shrub islands could alter soil nutrient content according to shrub size (Wang et al. 2011). As shrub size increases, the soil nutrient content diversifies. It may increase (Brantley \& Young 2010, Wang et al. 2011, Blaser et al. 2014), remain relatively stable (Hughes et al. 2006) or take on a unimodal distribution (Sasaki et al. 2010). However, few studies have focused on the effect of shrub island size on soil $\mathrm{C}: \mathrm{N}, \mathrm{N}: \mathrm{P}$ and $\mathrm{C}: \mathrm{P}$ ratios during shrub island expansion (Blaser et al. 2014, Rong et al. 2016). Therefore, it is still unclear how soil $\mathrm{C}: \mathrm{N}: \mathrm{P}$ stoichiometric ratios change with increasing shrub island size.

High-altitude forest cutovers colonized by scattered shrub species are found extensively on the eastern Tibetan Plateau as a consequence of the excessive logging of high-altitude forests nearby the timberline (3400-3900 $\mathrm{m}$ a.s.l.). The influence of such shrub islands on topsoil $\mathrm{C}, \mathrm{N}$ and $\mathrm{P}$ contents has been described in our previous study (Wang et al. 2011). In this paper, we utilize these shrub island-single element effects to investigate the secondary effect on C:N:P ratios. We expect that, in high-alti- 
tude forest cutovers, (1) shrub encrochment into meadows will change the $\mathrm{C}: \mathrm{N}: \mathrm{P}$ ratios in topsoil, and (2) the effect of shrub island presence on topsoil C:N:P ratios will vary among the four shrub species as well as with an increase in shrub island size.

\section{Materials and methods}

\section{Study site}

The present study was carried out at a clear-cut of an old-growth spruce forest near the timberline at Rike watershed in Zamtang County, northwest Sichuan Province, China $\left(32^{\circ} 19^{\prime} \mathrm{N}, 100^{\circ} 48^{\prime} \mathrm{E}\right)$. It is a typical high-altitude forest-grassland ecotone of the eastern Tibetan Plateau and it has a unique plateau monsoon climate with an annual average temperature of $4{ }^{\circ} \mathrm{C}$ and an annual average rainfall of $700-800 \mathrm{~mm}$. The research was conducted on an 18-year-old cutover (area: 5.3 ha; slope: $23^{\circ}$; aspect: NW $26^{\circ}$; elevation: $3650 \mathrm{~m}$ a.s.l.), where herbs and shrubs account for about $85 \%$ and $15 \%$ of total cover, respectively. The soils are categorized as Luvisols, which originate from metamorphic rocks, including phyllite, slate, and schist (Pang et al. 2011).

\section{Sampling design and nutrient analysis}

Eighty-six shrub islands containing four common deciduous shrub species with varying crown architecture, Cerasus trichostoma, Ribes glaciale, Rosa omeiensis and Salix sphaeronymphe (hereafter referred to as Cerasus, Ribes, Rosa and Salix, respectively) were selected for the study. In August 2008, several Cerasus, Ribes, Rosa and Salix shrub islands of different sizes were chosen and their corresponding basal area was measured in the field (Tab. 1). Each shrub island was regarded as a plot (86 plots in total). One subplot measuring $50 \times$ $50 \mathrm{~cm}\left(0.25 \mathrm{~m}^{2}\right)$ was sampled along the four directions (i.e., north, south, east and west) of each shrub island. Overall, we investigated 344 subplots, including 14 smaller subplots (area $<0.25 \mathrm{~m}^{2}$ ) under shrub islands with insufficient sampling size. In addition, 35 meadow plots, measuring $1 \times 1 \mathrm{~m}$, between shrub islands were established as controls (CK) where the same sampling and measurements of shrubs islands were repeated.

Litter coverage and mass were measured in each subplot, and then were used to respectively calculate litter coverage and mass at the plot-level. Topsoil $(0-20 \mathrm{~cm})$ samples were collected under shrub canopies and in the meadows by a soil auger to determine nutrient content. The three to five sub-samples collected in the subplot were combined into a composite sample for each shrub island plot. The litter samples were dried at $70{ }^{\circ} \mathrm{C}$ for $12-13$ hours in the laboratory before being weighed to determine dry mass (shrub plot litter biomass - Wang et al. 2011). All soil samples were air-dried, sieved through a 2-mm mesh and analyzed for total organic carbon (TOC) content by the Walkley-Black method, for total nitrogen content (TN) by the Kjeldahl method, and for total phosphorus content (TP) by Mo-Sb spectrophotometers.

\section{Data analyses}

The topsoil C:N, N:P and C:P ratios for all shrub islands and meadows were calculated as molar ratios. To examine whether shrub encroachment would change topsoil $\mathrm{C}: \mathrm{N}: \mathrm{P}$ stoichiometry in high-altitude forest cutovers, the element ratios between the 86 shrub island sample plots and the 35 meadow control plots were compared. The significance of difference in topsoil C:N, $\mathrm{N}: \mathrm{P}$ and $\mathrm{C}: \mathrm{P}$ ratios between meadows $(n=35)$ and shrub islands $(n=86)$ was tested by one-way analysis of variance (ANOVA). One-way ANOVA was also used to compare the differences between $\mathrm{C}: \mathrm{N}, \mathrm{N}: \mathrm{P}$ and $\mathrm{C}: \mathrm{P}$ ratios in topsoil among Ribes $(n=23)$, Cerasus $(n=22)$, Rosa $(n=21)$, Salix $(n=20)$ and meadows $(n=35)$.

Next, we log-transformed the shrub island area data to achieve normality, and performed a series of linear regression analyses to determine the relationships of

Tab. 1 - Basic characteristics of Cerasus (C. trichostoma), Ribes (R. glaciale), Rosa ( $R$. omeiensis) and Salix (S. sphaeronymphe) and surrounding topsoil C:N, N:P and C:P ratios in a high-altitude cutover of eastern Tibetan Plateau, China. Different lowercase letters indicate significant difference $(\mathrm{p}<0.05)$ among Cerasus, Ribes, Rosa, Salix and CK (meadow) after one-way ANOVA.

\begin{tabular}{|c|c|c|c|c|c|}
\hline $\begin{array}{l}\text { Type } \\
\text { (n) }\end{array}$ & Statistic & $\begin{array}{c}\text { Sample size } \\
\left(\mathrm{m}^{2}\right)\end{array}$ & $C: N$ & $\mathrm{~N}: \mathrm{P}$ & $C: P$ \\
\hline \multirow{2}{*}{$\begin{array}{l}\text { CK } \\
(n=35)\end{array}$} & Min - Max & 1 & $(13.8-23.7)$ & $(0.9-17.1)$ & $(166-291)$ \\
\hline & Mean \pm SE & 1 & $18.5 \pm 0.4^{\mathrm{a}}$ & $11.6 \pm 0.3^{\mathrm{a}}$ & $212 \pm 4^{\mathrm{a}}$ \\
\hline \multirow{2}{*}{$\begin{array}{l}\text { Cerasus } \\
(\mathrm{n}=22)\end{array}$} & Min - Max & $(0.6-11.1)$ & $(14.5-22.2)$ & $(10.6-23.5)$ & $(227-515)$ \\
\hline & Mean \pm SE & $3.51 \pm 0.52$ & $19.7 \pm 0.4^{\mathrm{a}}$ & $17.1 \pm 0.7^{b c}$ & $337 \pm 13^{b c}$ \\
\hline \multirow{2}{*}{$\begin{array}{l}\text { Ribes } \\
(n=23)\end{array}$} & Min - Max & $(0.6-7.3)$ & $(14.3-25.1)$ & $(11.6-28.3)$ & $(231-532)$ \\
\hline & Mean \pm SE & $2.4 \pm 0.3$ & $19.4 \pm 0.5^{\mathrm{a}}$ & $18.7 \pm 0.7^{c}$ & $362 \pm 16^{c}$ \\
\hline \multirow{2}{*}{$\begin{array}{l}\text { Rosa } \\
(\mathrm{n}=21)\end{array}$} & Min - Max & $(0.5-9.9)$ & $(15.8-22.7)$ & $(12.0-20.2)$ & $(197-438)$ \\
\hline & Mean \pm SE & $3.1 \pm 0.5$ & $19.2 \pm 0.4^{\mathrm{a}}$ & $16.4 \pm 0.5^{\mathrm{b}}$ & $317 \pm 15^{b}$ \\
\hline \multirow{2}{*}{$\begin{array}{l}\text { Salix } \\
(\mathrm{n}=20)\end{array}$} & Min - Max & $(0.6-12.4)$ & $(15.5-24.4)$ & $(10.0-30.0)$ & $(215-543)$ \\
\hline & Mean \pm SE & $4.6 \pm 0.9$ & $19.6 \pm 0.6^{a}$ & $16.7 \pm 0.9^{\mathrm{b}}$ & $328 \pm 19^{b c}$ \\
\hline
\end{tabular}

topsoil stoichiometric ratios ( $\mathrm{C}: \mathrm{N}, \mathrm{N}: \mathrm{P}$ and $\mathrm{C}: \mathrm{P}$ ratio) to both shrub island size and litter mass. We conducted analysis of covariance (ANCOVA) to test the differences between all intercepts and slopes of the above-mentioned linear regression equations among shrub species. Shrub island size and litter mass, as well as species and the soil stoichiometric ratios were both considered as covariate factors, fixed factors and dependent variables in ANCOVA. All data was analyzed by the software platform SPSS ${ }^{\circledast}$ ver. 20.0 (IBM, Armonk, NY, USA), and figures were made using the software Origin ${ }^{\circledast}$ ver. 9.0 (OriginLab Corp., Northampton, MA, USA).

\section{Results}

In the high-altitude cutover of the eastern Tibetan Plateau, the mean topsoil C:N, N:P and $C: P$ ratios of shrub islands $(n=86)$ were 19.5, 17.3 and 337, respectively. The ratios were significantly higher than that of the adjacent meadows (one-way ANOVA test: $\mathrm{n}=35 ; p=0.037, p<0.001$ and $p<0.001$, respectively). For shrubs at the species level, we found that the difference in topsoil $\mathrm{C}: \mathrm{N}$ ratios among the four shrub species and the meadows was not significant $(p=0.28)$ (Tab. 1), while both the topsoil N:P and C:P ratios of the four shrub species were always significantly higher than that of meadow (both $p<0.001)$. The highest and lowest soil $\mathrm{N}: \mathrm{P}$ and $\mathrm{C}: \mathrm{P}$ ratios occurred in Ribes (Tab. 1).

Pearson's correlation analysis indicated that both topsoil $\mathrm{C}$ and $\mathrm{N}$ contents were significantly related to litter mass beneath Cerasus ( $r=0.89$ and $r=0.76)$, Ribes $(r=0.82$ and $r=0.76)$, Rosa $(r=0.89$ and $r=0.83)$ and Salix ( $r=0.96$ and $r=0.75)$, all with $p<0.001$, whereas the topsoil $\mathrm{P}$ content did not relate to litter mass beneath Cerasus $(p=0.062)$, Ribes $(p=0.887)$, Rosa $(p=0.30)$, and Salix $(p=0.87)$. Topsoil $C: N$ ratios increased with accumulation of litter mass under Cerasus and Rosa (Fig. 1a). This relationship in slope of regression was larger for Rosa than for Cerasus, demonstrating that the topsoil C: $\mathrm{N}$ ratio increases with litter mass for Rosa more than for Cerasus.

Both topsoil N:P and C:P ratios under the four shrub species were significantly and positively correlated with litter mass (Fig. 1b, Fig. 1C). The slopes of both topsoil N:P and $C: P$ ratios were significant larger for Salix than for the other three species, indicating that the topsoil $\mathrm{N}: \mathrm{P}$ and $\mathrm{C}: \mathrm{P}$ ratios increase with litter mass for Salix more than for others (Fig. 1b, Fig. 1C). The topsoil C:N ratio increased with increasing shrub island size for Cerasus and Rosa, but this ratio did not change with shrub island size for Ribes and Salix (Fig. 2a). The difference in intercepts and slopes was not significant when comparing Cerasus and Rosa, which indicates that their increases in the topsoil $\mathrm{C}: \mathrm{N}$ ratio correlated with shrub island size to a similar degree in both species. Among all four species, topsoil $N: P$ and $C: P$ ratios were significantly and positively related to 
shrub island size (Fig. 2b, Fig. 2c). The regression slope did not differ among the four shrub species $(p=0.427$ and $p=0.383$, respectively), indicating that the topsoil $\mathrm{N}: \mathrm{P}$ and $\mathrm{C}: \mathrm{P}$ ratios similarly increased with shrub size, regardless of the species. The regression intercepts of both topsoil N:P and C:P ratios beneath Ribes were significantly higher than the other three shrubs ( $p<0.0001$ and $p<0.0001$, respectively), which indicates that, in our study, topsoil $\mathrm{N}: \mathrm{P}$ and $\mathrm{C}: \mathrm{P}$ ratios were greater under Ribes than under equally-sized shrub islands.

\section{Discussion}

In a high-altitude cutover on the eastern Tibetan Plateau, we found that shrub encroachment into meadows increased topsoil $\mathrm{N}: \mathrm{P}$ and $\mathrm{C}: \mathrm{P}$ ratios, regardless of shrub island size and species (Tab. 1, Fig. 2b, Fig. 2c). This result is consistent with previous findings (Xu et al. 2013, Blaser et al. 2014). In addition, our study showed that the topsoil C: $\mathrm{N}$ ratio was significantly larger around shrub islands $(n=86)$ than around adjacent meadows $(n=35)$. At the species level, the difference in ratios between the four shrub species and meadows was not significant (Tab. 1). These results strongly indicate that the shrub species composition largely impact on the difference in topsoil C:N ratios between shrub islands and meadows at a local level. Interestingly, shrub islands showed a decrease in topsoil $\mathrm{C}: \mathrm{N}$ ratios rather than the expected increase under small shrub size (i.e., by 0.5 $1.6 \mathrm{~m}^{2}$ - Fig. 2a). A decrease in topsoil C: $\mathrm{N}$ ratios from the meadows to the shrub islands agreed with observations in other studies (Springsteen et al. 2010, Blaser et al. 2014). Our previous studies have revealed an increase in topsoil $\mathrm{C}$ and $\mathrm{N}$ contents (Wang et al. 2011). Thus relatively low topsoil $\mathrm{C}: \mathrm{N}$ ratios could result from an intensive shrub island encroachments effect, even from an early stage of shrub establishment. Generally, the soil C: $\mathrm{N}$ ratio is negative to $\mathrm{N}$ mineralization rate. Once the shrub islands (Cerasus and Rosa) were established (Fig. 2a), the immediate and remarkable decrease in topsoil $\mathrm{C}: \mathrm{N}$ ratio indicated that $\mathrm{N}$ mineralization rates increase at the initial stage of shrub encroachment, which would enhance further encroachment of shrub islands onto adjacent meadows. Moreover, topsoil C: $\mathrm{N}$ ratios beneath meadows tend to be higher than that of relative larger shrub islands (shrub size > $1.6 \mathrm{~m}^{2}$ - Fig. 2a), as other reports have also found (Wheeler et al. 2007, McClaran et al. 2008, McKinley \& Blair 2008, Xu et al. 2013). Taken together, shrub encroachment onto meadows immediately lowered topsoil C:N ratios, but the ratios increased as the shrubs became established, especially in soil surrounding Salix and Ribes (Fig. 2a). This study suggests that shrub islands with diverse species and of various sizes significantly affect the succession trends of soil $\mathrm{C}: \mathrm{N}$ ratios as a meadow becomes a shrub
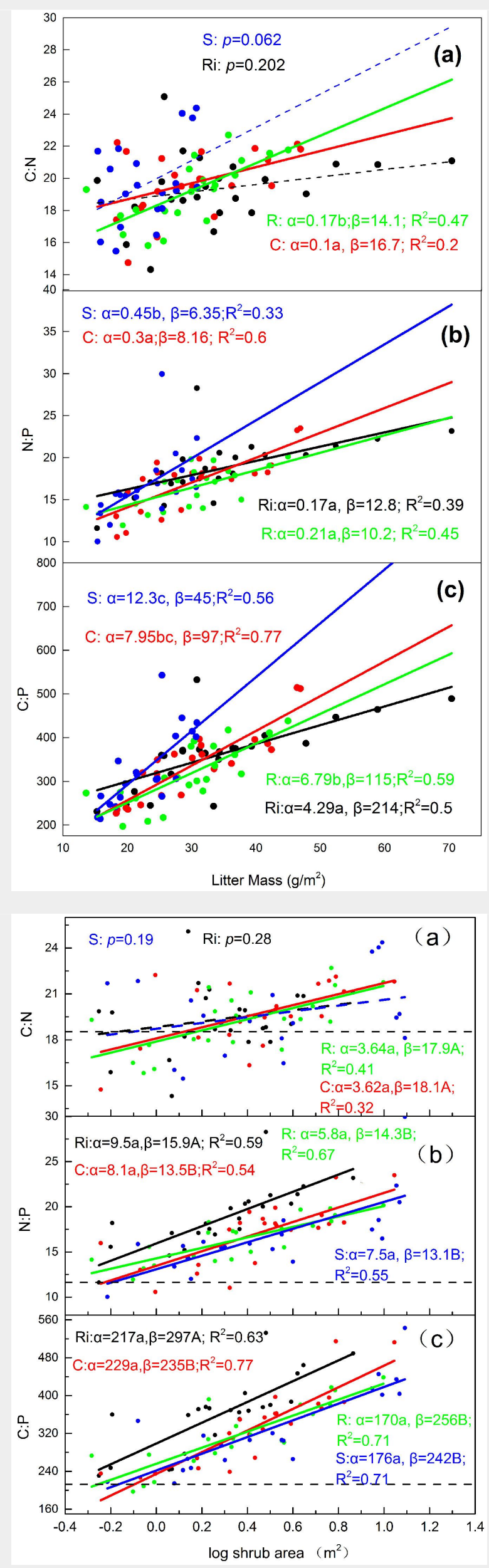

Fig. 1 - The relationship between litter mass ( $g$ $\mathrm{m}^{-2}$ ) and topsoil C:N, N:P and $\mathrm{C}: \mathrm{P}$ molar ratios can be represented by the following formula: $y=\alpha x+\beta$, $x$ and $y$ representing litter mass and soil stoichiometric ratios, respectively. A solid line indicates a signification relationship $(p<0.05)$, whereas a dashed line indicates a non-significant relationship ( $p>0.05)$. (R): Rosa; (Ri): Ribes; (C): Cerasus; (S): Salix.
Fig. 2 - The relationship between shrub area $\left(\mathrm{m}^{2}\right)$ and topsoil C: N, N:P and $C:$ P molar ratios for Cerasus, Ribes, Rosa and Salix island can be represented by the following formula: $y=\alpha \log (x)+\beta, x$ and $y$ representing shrub size and soil stoichiometric ratios, respectively. The horizontal dashed line represents $C: N: P$ ratios in the meadow soil. (R): Rosa; (Ri): Ribes; (C): Cerasus; (S): Salix. 
island. Consequently, our study provides an important explanation for the contradictory results of soil C: $\mathrm{N}$ ratios between grasslands and shrubs across various local and regions (Hughes et al. 2006, Wheeler et al. 2007, McClaran et al. 2008, McKinley \& Blair 2008, Springsteen et al. 2010, La Mantia et al. 2013).

Litter deposition is regarded as the main way to influence $C$ and nutrient contents in soil (Rinnan et al. 2008, La Mantia et al. 2013). Indeed, accumulation in litter mass of shrub islands was significantly and positively related to topsoil $\mathrm{C}$ and $\mathrm{N}$ content (all $p<0.001$ ), but it was not correlated with topsoil $\mathrm{P}$ content (all $p>0.06$ ). As a consequence, the accumulation of litter mass potentially led to higher topsoil $\mathrm{C}: \mathrm{N}, \mathrm{N}: \mathrm{P}$ and $\mathrm{C}: \mathrm{P}$ ratios (Fig. 1). Moreover, it has been stated that accumulation of litter mass is associated with shrub island expansion (Wang et al. 2011). Our study clearly shows that topsoil $\mathrm{C}: \mathrm{N}: \mathrm{P}$ ratios increase with increasing shrub island size (Fig. 2), which agrees with observations from Blaser et al. (2014). Thus, a distinct increase in topsoil $\mathrm{C}: \mathrm{N}: \mathrm{P}$ ratios can be partly ascribed to litter accumulation during shrub island expansion. These trends of increasing soil $\mathrm{C}: \mathrm{N}: \mathrm{P}$ ratios indicate a decline in mineralization rate of $\mathrm{N}$ and $\mathrm{P}$ as shrubs develop and further suggest that $P$ availability, rather than $\mathrm{N}$ availability, ultimately restrains the expansion of shrub islands. It has already been proven that $\mathrm{C}$ must combine nutrients ( $N$ and $P$ ) in a fixed ratio to subsequently be capable of sequestration in soil (Hessen et al. 2004, Kirkby et al. 2013). A larger $\mathrm{C}: \mathrm{N}: \mathrm{P}$ ratio usually indicates that a soil can store more $C$ per unit of nutrient ( $\mathrm{N}$ and $\mathrm{P}$ ). More importantly, this study further suggests that the presence of shrub islands in a high-altitude cutover improves topsoil C storage (Wang et al. 2011), with a higher $C$ sequestration efficiency of nutrients.

Schipper \& Sparling (2011) reported that soils undergo a change in C: $\mathrm{N}$ ratio when the vegetation landscape changes; soils with a higher initial C: $\mathrm{N}$ ratio rapidly declines in the $\mathrm{C}: \mathrm{N}$ ratio as shrub islands turn to pasture. Similarly, our study demonstrated that the increase in topsoil $\mathrm{C}: \mathrm{N}: \mathrm{P}$ ratios as shrub island size increases did not significantly vary among species (Fig. 2) because of the approximate $\mathrm{C}: \mathrm{N}: \mathrm{P}$ ratios in encroached meadow soils. Our results suggest that the response of stoichiometric ratio in topsoil to increasing shrub size is similar among species. Under conditions of less litter mass, topsoil $\mathrm{N}: \mathrm{P}$ and $\mathrm{C}: \mathrm{P}$ ratios in Ribes were relatively higher than in other three species (Fig. 1b, Fig. 1C). Ribes, with low branching and a hemispheroidal silhouette, was especially conducive to accumulating litter mass (Wang et al. 2011), thereby leading to larger $\mathrm{N}: \mathrm{P}$ and $\mathrm{C}: \mathrm{P}$ ratios in topsoil under shrubs of the same island size range (Tab. 1, Fig. 2b, Fig. 2c). Furthermore, Sasaki et al. (2010) stated that shrub islands could affect $\mathrm{N}: \mathrm{P}$ ratios with shrub biomass when enlarging shrub cover at the community level. Our results further provide a perspective of the effect of shrub islands on $\mathrm{C}$ and nutrient storage and their stoichiometric ratios in soil.

\section{Conclusions}

In a high-altitude forest cutover on the eastern Tibetan Plateau, the difference in the topsoil C: $\mathrm{N}$ ratios between meadows and shrub islands depended on shrub species and size. Topsoil N:P and C:P ratios in meadows were always lower than those in shrub islands, irrespective of species and size. Litter mass accumulation particularly resulted in an increase in topsoil $\mathrm{C}: \mathrm{N}: \mathrm{P}$ ratios. Topsoil C:N, N:P and C:P ratios significantly increased with increasing shrub island size, and had similar increasing rates among the four shrub species. Ribes always had a higher N:P and C:P ratio in topsoil, compared to other shrub islands of the same size. Therefore, our study provides a credible interpretation in diverse succession trends of soil $\mathrm{C}: \mathrm{N}$ ratio as grasslands become shrub-dominated, and suggests that shrub islands also affect soil C:N:P ratios with their size and species.

\section{Acknowledgements}

This work was funded by a grant from the National Natural Science Foundation of China (No. 31470023). D. Feng performed the statistical analysis and wrote the manuscript; W. Bao designed the experiments and revised the manuscript. We greatly appreciate Y. Wang, D. Yang, Z.H. Se, B. Cheng, C. Wang and X. Liu for their assistance with the field survey. We are grateful to the Zamtang Forestry Bureau for the help and support in the survey. We would also like to thank Elizabeth Tokarz at the Yale University for her assistance with English language and grammatical editing of this manuscript.

\section{References}

Alberti G, Vicca S, Inglima I, Belelli-Marchesini L, Genesio L, Miglietta F, Marjanovic H, Martinez C, Matteucci G, Andrea E, Peressotti A, Petrella F, Rodeghiero M, Cotrufo MF (2014). Soil C:N stoichiometry controls carbon sink partitioning between above-ground tree biomass and soil organic matter in high fertility forests. iForest Biogeosciences and Forestry 8: 195-206. - doi: 10.3832/ifor1196-008

Blaser WJ, Shanungu GK, Edwards PJ, Olde Venterink H (2014). Woody encroachment reduces nutrient limitation and promotes soil carbon sequestration. Ecology and Evolution 4: 14231438. - doi: 10.1002/ece3.1024

Brantley ST, Young DR (2010). Shrub expansion stimulates soil $\mathrm{C}$ and $\mathrm{N}$ storage along a coastal soil chronosequence. Global Change Biology 16: 2052-2061. - doi: 10.1111/j.1365-2486.2009.0212 9. $\mathrm{x}$

Cleveland CC, Liptzin D (2007). C:N:P stoichiometry in soil: is there a "redfield ratio" for the microbial biomass? Biogeochemistry 85: 235-252. doi: 10.1007/s10533-007-9132-0

Gundersen P, Sevel L, Christiansen JR, Vesterdal
L, Hansen K, Bastrup-Birk A (2009). Do indicators of nitrogen retention and leaching differ between coniferous and broadleaved forests in Denmark? Forest Ecology and Management 258: 1137-1146. - doi: 10.1016/j.foreco.2009.06. 007

Hessen DO, Agren GI, Anderson TR, Elser JJ, De Ruiter PC (2004). Carbon, sequestration in ecosystems: the role of stoichiometry. Ecology 85: 1179-1192. - doi: 10.1890/02-0251 Hughes RF, Archer SR, Asner GP, Wessman (A, McMurtry C, Nelson J, Ansley RJ (2006). Changes in aboveground primary production and carbon and nitrogen pools accompanying woody plant encroachment in a temperate savanna. Global Change Biology 12: 1733-1747. doi: 10.1111/J.1365-2486.2006.01210.x

Kirkby CA, Richardson AE, Wade LJ, BattenBGD, Blanchard C, Kirkegaard JA (2013). Carbon-nutrient stoichiometry to increase soil carbon sequestration. Soil Biology and Biochemistry 60: 77-86. - doi: 10.1016/j.soilbio.2013.01.011

Klemedtsson L, Von Arnold K, Weslien P, Gundersen $P$ (2005). Soil CN ratio as a scalar parameter to predict nitrous oxide emissions. Global Change Biology 11: 1142-1147. - doi: 10.1111/j.13652486.2005.00973.x

La Mantia T, Gristina L, Rivaldo E, Pasta S, Novara A, Ruhl J (2013). The effects of post-pasture woody plant colonization on soil and aboveground litter carbon and nitrogen along a bioclimatic transect. iForest - Biogeosciences and Forestry 6: 238-246. - doi: 10.3832/iforo811006

McClaran MP, Moore-Kucera J, Martens DA, Van Haren J, Marsh SE (2008). Soil carbon and nitrogen in relation to shrub size and death in a semi-arid grassland. Geoderma 145: 60-68. - doi: 10.1016/j.geoderma.2008.02.006

McKinley DC, Blair JM (2008). Woody plant encroachment by Juniperus virginiana in a mesic native grassland promotes rapid carbon and nitrogen accrual. Ecosystems 11: 454-468. - doi: 10.1007/s10021-008-9133-4

Pang XY, Bao WK, Wu N (2011). The effects of clear-felling subalpine coniferous forests on soil physical and chemical properties in the eastern Tibetan Plateau. Soil Use and Management 27: 213-220. - doi: 10.1111/j.1475-2743.2010.00324.x Rinnan R, Michelsen A, Jonasson S (2008). Effects of litter addition and warming on soil carbon, nutrient pools and microbial communities in a subarctic heath ecosystem. Applied Soil Ecology 39: 271-281. - doi: 10.1016/j.apsoil.2007. 12.014

Rong Q, Liu J, Cai Y, Lu Z, Zhao Z, Yue W, Xia J (2016). "Fertile island" effects of Tamarix chinensis Lour. on soil $\mathrm{N}$ and $\mathrm{P}$ stoichiometry in the coastal wetland of Laizhou Bay, China. Journal of Soils and Sediments 16: 864-877. - doi: 10.1007/s11368-015-1296-y

Sasaki T, Yoshihara Y, Jamsran U, Ohkuro T (2010). Ecological stoichiometry explains largerscale facilitation processes by shrubs on species coexistence among understory plants. Ecological Engineering 36: 1070-1075. - doi: 10.1016/j.ecoleng.2010.04.020

Schipper LA, Sparling GP (2011). Accumulation of soil organic $C$ and change in $\mathrm{C}$ : $\mathrm{N}$ ratio after establishment of pastures on reverted scrubland in New Zealand. Biogeochemistry 104: 49-58. 
doi: $10.1007 /$ s10533-009-9367-z

Sistla SA, Schimel JP (2012). Stoichiometric flexibility as a regulator of carbon and nutrient cycling in terrestrial ecosystems under change. New Phytologist 196: 68-78. - doi: 10.1111/j.14698137.2012.04234.x

Springsteen A, Loya W, Liebig M, Hendrickson J (2010). Soil carbon and nitrogen across a chronosequence of woody plant expansion in North Dakota. Plant and Soil 328: 369-379. - doi: 10.1007/s11104-009-0117-8
Sterner RW, Elser JJ (2002). Ecological stoichiometry: the biology of elements from molecules to the biosphere. Princeton University Press, Princeton, NJ, USA, pp. 464. - doi: 10.1515/97 81400885695

Wang YC, Bao WK, Wu N (2011). Shrub island effects on a high-altitude forest cutover in the eastern Tibetan Plateau. Annals of Forest Science 68: 1127-1141. - doi: 10.1007/s13595-011-012 8-5

Wheeler CW, Archer SR, Asner GP, McMurtry CR
(2007). Climatic/edaphic controls on soil carbon/nitrogen response to shrub encroachment in desert grassland. Ecological Applications 17: 1911-1928. - doi: 10.1890/06-1580.1 Xu XF, Thornton PE, Post WM (2013). A global analysis of soil microbial biomass carbon, nitrogen and phosphorus in terrestrial ecosystems. Global Ecology and Biogeography 22: 737-749. doi: 10.1111/geb.12029 